\title{
THE EFFECT OF ANGIOTENSIN II RECEPTOR BLOCKER VALSARTAN ON THE LEVEL OF CIRCULATING ENDOTHELIAL PROGENITOR CELLS IN DIABETIC PATIENTS WITH CHRONIC HEART FAILURE
}

\section{O.O.Kremzer}

\author{
Zaporizhzhia State Medical University
}

Key words: coronary heart disease; diabetes; heart failure; endothelial progenitor cells; valsartan

\begin{abstract}
Reduction of circulating endothelial progenitor cells (EPCS) are considered as strong and robust biomarkers for prediction of cardiovascular outcomes in both chronic heart failure and diabetic populations. The aim of this study was to assess the effect of angiotensin II receptor blocker valsartan on the circulating level of endothelial progenitor cells in patients with ischemic chronic heart failure and type two diabetes mellitus (T2DM). The study population was structured retrospectively after determining coronary artery disease by multispiral computed tomography / contrast enhanced angiography in 126 subjects with chronic heart failure. Blood samples were taken at baseline before valsartan given and in 52 weeks after study entry. Endothelial progenitor cell populations were phenotyped by flow cytofluorimetry by means of monoclonal antibodies labeled with fluorochromes. Proangiogenic circulating EPCs were identified as CD45CD34+. CD133, CD309 (VEGFR2), and Tie-2 antigens were also determined to identify subpopulations of EPCs coexpressing CD14 antigen. All subjects were distributed into two cohorts depending on daily doses of valsartan. Low (80-160 mg daily orally) and high doses (240-320 mg daily orally) of valsartan were used, and they were adjusted depending on achievement of the blood pressure level less than $140 / 80 \mathrm{~mm} \mathrm{Hg}$. The finding may suggest that the positive effect of valsartan on the endothelial function might be implemented by involving EPCs in reparative processes of vasculature in subjects with ischemic chronic heart failure with T2DM and thereby to improve the long-term prognosis in this patient population. The change from baseline in CD34 ${ }^{+}$subset of EPCs (frequencies and absolute values) was not significantly different between treatment cohorts. There was a significant increase of the circulating level of $C D 14^{+} \mathrm{CD} 309^{+}$cells in two patient cohorts. But more prominent change of CD14+CD309+cells was observed in subjects who were given valsartan in high daily doses when compared with persons who were included into the cohort with low daily doses of the drug $(P<0.05)$. Therefore, both frequencies and absolute values in $\mathrm{CD}_{14} \mathrm{CDD}^{+} 09^{+} \mathrm{Tie}^{+}$were increased significantly in patients who were treated with high doses of valsartan only. A positive influence of angiotensin II receptor blocker valsartan in escalation doses on bone marrow-derived EPCs phenotyped as $C D 14^{+} C D 309^{+}$and $C D 14^{+} C D 309^{+}$Tie2 ${ }^{+}$in patients with ischemic chronic heart failure and T2DM has been found.
\end{abstract} Type two diabetes mellitus mon cause of early manifestation of atherosclerosis and chronic heart failure that leads to increased cardiovascular morbidity and mortality [10]. It has been suggested that progression of atherosclerosis and myocardial dysfunction in T2DM patients may be related to endothelial dysfunction, that, probably, is mediated by suppression of the bone marrow-derived endothelial progenitor cells (EPCs) level in circulation, as well as decrease of the functional activity of EPCs $[4,15]$. It has been previously found that EPC with the hematopoietic origin and the phenotype of $\mathrm{CD} 34^{+} \mathrm{CD} 45$ are actively involved in angiogenesis, neovascularization, and tissue repair
$[13,15]$. Decrease in the population of circulating CD34+CD45 cells in patients with coronary heart disease (CHD), peripheral artery disease and dyslipidemia is associated with both severity of atherosclerotic lesions and severity of the arterial endothelial dysfunction $[8,12,19]$. However, circulating EPCs are considered as strong and robust biomarkers for prediction of cardiovascular outcomes in some populations, such as CAD and T2DM [4]. However, the most reliable prognostic indicators were not CD $34^{+}$EPA $\left(C D 45^{+} \mathrm{CD} 34^{+}\right.$and CD $45^{-} \mathrm{CD} 4^{+}$), but EPA with potentially proangiogenic qualities with phenotypes $\mathrm{CD} 14^{+} \mathrm{CD} 309^{+}$and $\mathrm{CD}^{+} 4^{+} \mathrm{CD} 309^{+} \mathrm{Tie}^{+}$[1]. Thus, proangiogenic EPA can be considered as early markers of the benefici- al effects of different modes of therapy in relation to short-term and long-term prognosis.

The aim of this study was to assess the effect of angiotensin II receptor blocker valsartan on the circulating level of endothelial progenitor cells in patients with ischemic chronic heart failure in combination with type two diabetes mellitus (T2DM).

\section{Materials and Methods}

The study population was structured retrospectively after determining coronary artery disease by multispiral computed tomography / contrast enhanced angiography or X-ray contrast angiography in 126 subjects with CHF (I-II functional class, NYHA classification). All patients gave voluntary written informed consent to participate in the study. Exclusion criteria were left ventricular ejection fraction 
(LVEF) $\leq 40 \%$; severe kidney and liver diseases, which may affect the clinical outcome; unstable angina, myocardial infarction, or intracranial hemorrhage within 30 days prior to the study; the level of plasma creatinine above $440 \mathrm{mmol} / \mathrm{l}$; the glomerular filtration rate (GFR) $<35 \mathrm{~mL} / \mathrm{min} / \mathrm{m}^{2}$; the body mass index above $30 \mathrm{~kg} / \mathrm{m}^{2}$; hemodynamically significant tachyarrhythmias; valvular heart disease; hyperthyroidism; all cardiovascular ischemic events occurred during three months preceding the beginning of the research; cancer; cardiac pacemakers; pregnancy.

Contrast-Enhanced Spiral Computed Tomography Angiography

In order to verify the nature of a coronary disease patients underwent multispiral computed tomography-angiography and/or angiography. The CHD diagnosis was considered to be determined with the presence of angiographic studies performed previously and not older than 6 months in the absence of new cardiovascular events during this period and availability of results of the procedure for quantitative analysis. The coronary artery wall structure, as well as geometric and compositional parameters of atheromas were measured by contrast spiral CT on a "Somatom Volume Zoom" scanner (Siemens, Erlangen, Germany) with 2 rows of detectors during breath holding at the end of exhalation. After a preliminary scanning introduction of non-ionic contrast "Omnipak" (Amersham Health, Ireland) used to obtain optimal images of the coronary arteries was performed. For the reconstruction of images axial tomographic slices with the width of $0.6 \mathrm{~mm}$ were used. Coronary artery calcification was quantified by calculating the Agatston index [3]. Besides, the presence of calcified atheromas, but not calcified atherosclerotic plaques of high and low density, respectively, was determined according to the traditional methods $[2,7]$.

\section{tion}

Echocardiography Examina-

According to recommendations of the American Society of Echocardiography, standard transthoracic echocardiography in B-mode was performed on an ACUSON S30 scanner (Siemens, Erlangen, Germany) using a transducer with a frequency of 2.5-5 MHz. End-diastolic and end-systolic $\mathrm{LV}$ volumes were obtained using a two-dimensional reference sector according to the Simpson method, and the LV ejection fraction (LVEF) was calculated according to the conventional methods [20].

Evaluation of the glomerular

\section{filtration rate}

Evaluation of the glomerular filtration rate (eGFR) was calculated using the MDRD formula [15].

Calculation of the cardiovascular risk value

Calculation of the 10-year cardiovascular risk in the patients studied was performed according to the Framingham scale of the total cardiovascular risk (2008) using the on-line calculator.

Measurement of circulating levels of biological markers

Blood samples were taken at baseline, prior to application of valsartan and 52 weeks after the start of the study. All serum samples were placed in tubes containing EDTA for subsequent analysis by flow cytometry. After collection of the blood for analysis all samples were placed in chilled test-tubes and immediately centrifuged at the rotation speed of $6000 \mathrm{rpm}$. After centrifugation the serum was encoded and stored in a refrigerator at $-70^{\circ} \mathrm{C}$ until use.

The level of high-sensitivity $\mathrm{C}$-reactive protein (hs-CRP) was measured using a "AU640" nephelometric technique analyzer (Olympus Diagnostic Systems Group, Japan). The content of uric acid in the blood serum was determined by the enzymatic method. The concentrations of total cholesterol (TC) and high density lipoprotein (HDL) cholesterol were determined by an "AU640" analyzer (Olympus Dia- gnostic Systems Group, Japan). Lowdensity lipoproteins (LDL) were calculated using the Friedewald formula [11]. Microalbuminuria was verified as the loss of albumin in the range of 30-300 mg/day.

Phenotyping of EPC populations was carried out by the flow cytometry using monoclonal antibodies labeled with fluorochromes, FITC (fluorescein isothiocyanate) or double-labeled FITC/PE (phycoerythrin) (BD Biosciences, USA), antigens CD45, CD34, CD14, Tie-2 and SD309 (VEGFR2) according to the HD-FACS methodology (High-Definition Fluorescence Activated Cell Sorter) with mandatory removal of erythrocytes with the lysing buffer according to the protocol of ISHAGE gating [21]. For each sample 500000 events were analyzed. Circulating EPC were defined as CD45 CD34+. To identify subpopulations of EPC co-expressing antigen CD14, antigens SD309 (VEGFR2) and Tie-2 were determined additionally. The results of scattergrams obtained in the longitudinal and transverse dispersal of the laser beam in the flow cytofluorimeter were analyzed using the Boolean principles for double or triple positive events. The total number of identified cells was standardized with respect to the concentration of circulating CD $45^{+}$mononuclear cells.

Researchers strictly adhered to all the requirements for clinical trials according to the Helsinki Declaration of Human Rights (1964), the Conference on Harmonization Good Clinical Practice (GCP-ICH), Council of Europe Convention on protection of human rights and dignity in relation to the application of achievements of biology and medicine, the Convention on human rights and biomedicine, including the Additional Protocol to the Convention on biomedical research and legislation of Ukraine.

\section{Statistical Analysis}

All the statistical analyses were performed in SPSS for Windows v. 20.0 (SPSS Inc., Chicago, IL, USA, 
2011). Continuous variables are presented as mean $\pm \mathrm{SD}$, mean and 95\% CI or median and the interquartile range. Categorical variables are expressed as frequencies and percentage. An independent group t-test was used to compare all the interval parameters matching the criteria of normality and homogeneity of variance. For interval parameters that fail to match these criteria the non-parametric Mann-Whitney test was used to compare variables. Categorical variables and frequencies were compared using $\chi 2$ test and Fisher exact test of independence. SUA frequencies were normally distributed (using the Kolmogorov-Smirnov test), and data were not positively skewed. Frequencies of CMCs and hs-CRP concentrations were not distributed. The data, however, were not transformed. A calculated difference of $\mathrm{P}<0.05$ was considered to be significant.

General characteristics of the patients participating in the study are presented in Table 1 . The group studied was represented predominantly by male $(62.8 \%)$ aged $58.34 \pm 9.60$ years old. Among the comorbidities and comorbid conditions there were a moderate hypertension (65.1\%), dyslipidemia (51.2\%), microalbuminuria (34.9\%), and smoking (18.6\%). Premature coronary artery disease in the family history was recorded in $10.5 \%$ of the patients. The estimated value of the total 10 -year cardiovascular risk was 16\%-27\% $(\mathrm{M}=23 \%)$. Calcified atheromas ( $\mathrm{n}=56$ ) were detected in $96 \%$ of the patients, noncalcified and low and high densities atheromas were found in $24.4 \%$ and $17.4 \%$, respectively. The median of the Agatston index was 586 (95\% CI = 401-838). Single-, two- and multivessel coronary artery disease was determined in $30.3 \% 25.6 \%$ and $44.2 \%$ of the patients, respectively. All patients with ischemic $\mathrm{CHF}$ were treated in accordance with the current clinical guidelines, namely diet, lifestyle modification and drug therapy that included angiotensin II receptor blocker valsartan, $\beta$-blocker bisoprolol in target doses (10 mg/day), aspirin or other antiplatelet agents, a loop diuretic, statins and metformin, if necessary. Among the patients selected there were no persons requiring additional prescription of insulin or other antidiabetic medicines, except metformin.

The patients were divided into two groups depending on the daily dose of valsartan. Relatively low (80-160 mg per day) and high (240-320 mg daily) doses of valsartan were adjusted according to the achievement of the blood pressure level less than 140/80 $\mathrm{mm} \mathrm{Hg}$ as $63.0 \%$ and $67.5 \%$ of the patients in both groups had a mild hypertension. Furthermore, microalbuminuria was detected in $37.0 \%$ and $32.5 \%$ of the patients, respectively. Both groups under study were matched in the frequency of cardiovascular risk factors, the body mass index, systolic and diastolic blood pressure, left ventricular ejection fraction, the heart rate, serum creatinine, glucose, glycated gemoglobin (HbA1c), uric acid and GFR. Increase in the concentration of hs-CRP, as well as decrease of LDL cholesterol levels were found in the patients with chronic heart failure and type 2 diabetes receiving high doses of valsartan compared to the patients who received valsartan in lower doses. Medians of the 10-year total cardiovascular risk were $22 \%$ and $24 \%$ for both groups of the patients with low and high daily dose of valsartan, respectively. The number of coronary arteries with the atheromas documented, as well as characteristics of the latter were comparable for both groups of the patients. There were no significant differences between the groups of the patients with chronic heart failure and type 2 diabetes in relation to the dynamics of blood pressure. In all patients with arterial hypertension in both groups the target blood pressure (less than $140 / 80 \mathrm{~mm} \mathrm{Hg}$ ) was achieved. Diuretics were added to the treat- ment regimen in $10.9 \%$ and $10.0 \%$ of cases, respectively. The mean systolic and diastolic blood pressure in both groups of patients in week 52 after the start of the study was $132 \pm 4 / 73 \pm 3 \mathrm{mmHg}$ and $134 \pm 4 / 75 \pm 4 \mathrm{mmHg}(\mathrm{p}=0.66)$.

Analysis of the results showed no significant changes in the content of the EPC with the phenotypes of $\mathrm{CD} 45^{+} \mathrm{CD} 34^{+}$, and $\mathrm{CD} 45^{-} \mathrm{CD} 34^{+}$, $\mathrm{CD}_{14}{ }^{+} \mathrm{CD} 309^{+}$and $\mathrm{CD} 14^{+} \mathrm{CD} 309^{+} \mathrm{Tie}^{+}{ }^{+}$ between groups of the patients at baseline prior to the prescription of valsartan (Table 2). The nature of the effect of treatment with valsartan in different daily doses on the level of circulating EPC is shown in Table 3. As seen from the Table, the change in the total number of $\mathrm{CD}^{4} 4^{+}$of EPC in two groups of the patients during the observation period has no statistically significant character ( $p>0.2$ for all cases). In contrast, there was a significant increase in the level of circulating CD $14^{+}$CD $309^{+}$EPC by the end of week 52 of the therapy in two groups of patients. However, a more pronounced dynamics was observed in patients receiving valsartan in high daily doses $(\mathrm{p}<0.05)$. Thus, the content of valsartan provided a distinct dose-dependent effect on circulating levels of pro-angiogenic EPC with the phenotypes of $\mathrm{CD}^{+} 4^{+} \mathrm{CD} 309^{+}$and CD14 $4^{+} \mathrm{CD} 309^{+} \mathrm{Tie}^{+}$, while $\mathrm{CD}_{34}{ }^{+}$pool of EPC did not undergo significant changes within the whole observation period.

\section{Results and Discussion}

It has been determined that EPC derived from the bone marrow and less often from peripheral tissues maintain the integrity of the vascular endothelium, as well as participate in vascular repair, angiogenesis and revascularization [22]. The number of circulating EPC increases in response to ischaemia and usually decreases with asymptomatic atherosclerosis, stable angina, type 2 diabetes, dyslipidemia, obesity $[5,8,17,18]$. According to the findings of the experimental studies, EPC with the phenotypes of CD $14^{+} \mathrm{CD} 309^{+}$and 


\section{General characteristics of patients under research}

\begin{tabular}{|c|c|c|c|c|}
\hline \multirow[b]{2}{*}{ Parameters } & \multicolumn{3}{|c|}{ T2DM patients with CHF } & \multirow[b]{2}{*}{$P$ value } \\
\hline & All patients $(n=86)$ & $\begin{array}{l}\text { Cohort with a low daily } \\
\text { dose of valsartan }(n=46)\end{array}$ & $\begin{array}{l}\text { Cohort with a high daily } \\
\text { dose of valsartan }(n=40)\end{array}$ & \\
\hline Age, years & $58.34 \pm 9.60$ & $57.98 \pm 8.12$ & $59.32 \pm 7.55$ & 0.52 \\
\hline Male, n (\%) & $54(62.8 \%)$ & $28(60.9 \%)$ & $26(65.0 \%)$ & 0.58 \\
\hline $\begin{array}{l}\text { Framingham General } \\
\text { Cardiovascular Risk, \% }\end{array}$ & $23(16-27)$ & $22(17-25)$ & $24(16-30)$ & 0.001 \\
\hline Arterial hypertension, $\mathrm{n}(\%)$ & $56(65.1 \%)$ & $29(63.0 \%)$ & 27 (67.5\%) & 0.48 \\
\hline Dyslipidemia, n (\%) & $44(51.2 \%)$ & $24(52.2 \%)$ & $20(50.0 \%)$ & 0.58 \\
\hline Microalbuminuria, n (\%) & $30(34.9 \%)$ & $17(37.0 \%)$ & $13(32.5 \%)$ & 0.52 \\
\hline Premature CAD, $\mathrm{n}(\%)$ & $9(10.5 \%)$ & $4(8.7 \%)$ & $5(12.5 \%)$ & 0.048 \\
\hline Smoking, n (\%) & $16(18.6 \%)$ & $10(21.7 \%)$ & $6(15.0 \%)$ & 0.042 \\
\hline Body mass index, $\mathrm{kg} / \mathrm{m}^{2}$ & $24.1(95 \% \mathrm{Cl}=21.6-26.1)$ & $22.5(95 \% \mathrm{Cl}=20.3-26.0)$ & $25.2(95 \% \mathrm{Cl}=20.6-27.2)$ & 0.055 \\
\hline eGFR, $\mathrm{ml} / \mathrm{min} / \mathrm{m}^{2}$ & $82.3(95 \% \mathrm{Cl}=68.7-102.6)$ & $85.4(95 \% \mathrm{Cl}=70.1-98.2)$ & $82.1(95 \% \mathrm{Cl}=67.5-01.3)$ & 0.36 \\
\hline $\mathrm{HbA} 1 \mathrm{c}, \%$ & $6.8(95 \% \mathrm{Cl}=4.1-9.5)$ & $6.69(95 \% \mathrm{Cl}=4.8-9.32)$ & $6.85(95 \% \mathrm{Cl}=4.2-9.5)$ & 0.061 \\
\hline Fasting glucose, $\mathrm{mmol} / \mathrm{L}$ & $5.20(95 \% \mathrm{Cl}=3.3-9.7)$ & $5.16(95 \% \mathrm{Cl}=3.7-8.8)$ & $5.24(95 \% \mathrm{Cl}=3.2-9.6)$ & 0.057 \\
\hline Creatinine, $\mu \mathrm{mol} / \mathrm{L}$ & $72.3(95 \% \mathrm{Cl}=58.7-92.6)$ & $75.7(95 \% \mathrm{Cl}=57.1-90.4)$ & $71.2(95 \% \mathrm{Cl}=56.4-98.9)$ & 0.49 \\
\hline $\mathrm{SUA}, \mathrm{mmol} / \mathrm{L}$ & $23.8(95 \% \mathrm{Cl}=15.8-31.3)$ & $23.4(95 \% \mathrm{Cl}=15.6-30.1)$ & $23.9(95 \% \mathrm{Cl}=16.9-31.6)$ & 0.48 \\
\hline $\mathrm{hs-CRP,} \mathrm{mg/L}$ & $4.95(95 \% \mathrm{Cl}=3.15-9.80)$ & $4.87(95 \% \mathrm{Cl}=3.66-9.10)$ & $5.22(95 \% \mathrm{Cl}=3.11-9.93)$ & 0.046 \\
\hline $\mathrm{TC}, \mathrm{mmol} / \mathrm{L}$ & $5.1(95 \% \mathrm{Cl}=3.9-6.1)$ & $5.0(95 \% \mathrm{Cl}=3.7-6.0)$ & $5.3(95 \% \mathrm{Cl}=3.8-5.8)$ & 0.12 \\
\hline LDL cholesterol, mmol/L & $3.23(95 \% \mathrm{Cl}=3.11-4.4)$ & $3.31(95 \% \mathrm{Cl}=3.09-4.28)$ & $3.23(95 \% \mathrm{Cl}=3.11-4.4)$ & 0.047 \\
\hline HDL cholesterol, $\mathrm{mmol} / \mathrm{L}$ & $0.91(95 \% \mathrm{Cl}=0.89-1.12)$ & $0.93(95 \% \mathrm{Cl}=0.90-1.10)$ & $0.90(95 \% \mathrm{Cl}=0.87-1.12)$ & 0.18 \\
\hline Mean systolic BP, mm Hg & $144 \pm 8$ & $144 \pm 5$ & $146 \pm 7$ & 0.44 \\
\hline Mean diastolic BP, $\mathrm{mm} \mathrm{Hg}$ & $84 \pm 5$ & $85 \pm 4$ & $83 \pm 6$ & 0.56 \\
\hline Heart rate, beat per min & $71 \pm 3$ & $72 \pm 4$ & $69 \pm 4$ & 0.52 \\
\hline LV EF, \% & $48.10 \pm 0.76$ & $48.50 \pm 0.58$ & $48.80 \pm 0.34$ & 0.64 \\
\hline CAP, $n$ & $56(95 \% \mathrm{Cl}=31-76)$ & $52(95 \% \mathrm{Cl}=46-78)$ & $59(95 \% \mathrm{Cl}=42-79)$ & 0.44 \\
\hline HD-NCP, $n$ & $21(95 \% \mathrm{Cl}=11-46)$ & $19(95 \% \mathrm{Cl}=13-39)$ & $24(95 \% \mathrm{Cl}=11-48)$ & 0.63 \\
\hline LD-NCP, $n$ & $15(95 \% \mathrm{Cl}=13-21)$ & $16(95 \% \mathrm{Cl}=13-20)$ & $13(95 \% \mathrm{Cl}=11-17)$ & 0.38 \\
\hline Agatston score index & $586(95 \% \mathrm{Cl}=401-838)$ & $579(95 \% \mathrm{Cl}=466-820)$ & $592(95 \% \mathrm{Cl}=412-844)$ & 0.60 \\
\hline \multicolumn{5}{|l|}{$\begin{array}{l}\text { Coronary arteries with } \\
\text { plaques determined }\end{array}$} \\
\hline Single-vessel disease, n (\%) & $26(30.3 \%)$ & $13(28.3 \%)$ & $13(32.5 \%)$ & 0.058 \\
\hline Two-vessel disease, n (\%) & $22(25.6 \%)$ & $12(26.1 \%)$ & $10(25.0 \%)$ & 0.62 \\
\hline Multivessel disease, n (\%) & $38(44.2 \%)$ & $21(45.6 \%)$ & $17(42.54 \%)$ & 0.54 \\
\hline Aspirin, $n(\%)$ & $81(94.1 \%)$ & $43(93.5 \%)$ & 38 (95.0\%) & 0.38 \\
\hline Other antiagregants, n (\%) & $5(5.8 \%)$ & $3(6.5 \%)$ & $2(5.0 \%)$ & 0.36 \\
\hline Statins, n (\%) & $56(65.1 \%)$ & $29(63.0 \%)$ & $27(67.5 \%)$ & 0.48 \\
\hline Metformin, n (\%) & $44(51.2 \%)$ & $24(52.2 \%)$ & $20(50.0 \%)$ & 0.58 \\
\hline Thiazide-like diuretic, n (\%) & $9(10.5 \%)$ & $5(10.9 \%)$ & $4(10.0 \%)$ & 0.82 \\
\hline
\end{tabular}

Note: $\mathrm{Cl}$ - confidence interval, T2DM - type 2 diabetes mellitus, eGFR - estimated glomerulal filtration ratio, TC - total cholesterol, HbA1c - glycated hemoglobin, LDL - low-density cholesterol, HDL - high-density cholesterol, SUA - serum uric acid, BP - blood pressure, hs-CRP - high sensitive C-reactive protein, LV EF - left ventricular ejection fraction, HD-NCP - high-density noncalcified atherosclerotic plaque, LD-NCP - low-density noncalcified atherosclerotic plaque, CAP - calcified atherosclerotic plaques.

$\mathrm{CD}_{14}{ }^{+} \mathrm{CD} 309^{+} \mathrm{Tie}^{+}$contribute to the restoration of the endothelium of the arteries, and it is the necessary condition for repair of blood vessels [12]. It has been found that reduction in $\mathrm{CD} 14^{+} \mathrm{CD} 309^{+}$ and $\mathrm{CD} 14^{+} \mathrm{CD} 309^{+} \mathrm{Tie}^{+}$of $\mathrm{EPC}$ is closely associated with cardiovascular risk factors and has a predictive value for occurrence of adverse cardiovascular outcomes [4, 12]. The present study has tested the hypothesis that in patients with ischemic CHF in conbination with the accompanying type 2 diabetes the level of recovery of circulating EPC can be achieved after prolonged use of angiotensin II recep- 


\section{Frequencies and absolute values of circulating mononuclear cells in the study patient population}

\begin{tabular}{|c|c|c|c|c|}
\hline \multirow[b]{2}{*}{ Parameters } & \multicolumn{3}{|c|}{ T2DM patients with the known CAD } & \multirow[b]{2}{*}{$P$ value } \\
\hline & All patients $(n=86)$ & $\begin{array}{l}\text { Cohort with a low daily } \\
\text { dose of valsartan }(n=46)\end{array}$ & $\begin{array}{l}\text { Cohort with a high daily } \\
\text { dose of valsartan }(n=40)\end{array}$ & \\
\hline $\mathrm{CD}_{4} 5^{+} \mathrm{CD} 34^{+}, \%$ & $2.19(\mathrm{IQR}=1.76-2.613)$ & $2.14(\mathrm{IQR}=1.79-2.50)$ & $2.23(\mathrm{IQR}=1.74-2.751)$ & 0.36 \\
\hline $\mathrm{CD}^{2} 5^{+}{ }^{2} 34^{+}$, cells $\times 10^{3} / \mu \mathrm{L}$ & $0.113(\mathrm{IQR}=0.094-0.119)$ & $0.114(\mathrm{IQR}=0.095-0.120)$ & $0.113(\mathrm{IQR}=0.092-0.121)$ & 0.72 \\
\hline $\mathrm{CD}_{45} \mathrm{CD}^{-} 4^{+} \times 10^{-4}, \%$ & $1.09(\mathrm{IQR}=1.00-1.348)$ & $1.07(\mathrm{IQR}=0.99-1.35)$ & $1.10(\mathrm{IQR}=0.99-1.365)$ & 0.55 \\
\hline $\mathrm{CD}^{2} \mathrm{CD}^{-} 4^{+}$, cells $\times 10^{-1} / \mu \mathrm{L}$ & $0.057(\mathrm{IQR}=0.053-0.065)$ & $0.055(\mathrm{IQR}=0.052-0.067)$ & $0.058(\mathrm{IQR}=0.051-0.068)$ & 0.62 \\
\hline $\mathrm{CD}_{14}{ }^{+} \mathrm{CD} 309^{+} \times 10^{-4}, \%$ & $57.00(\mathrm{IQR}=43.20-81.50)$ & $57.00(\mathrm{IQR}=41.50-76.90)$ & $58.10(\mathrm{IQR}=43.50-82.80)$ & 0.52 \\
\hline $\mathrm{CD}_{14}{ }^{+} \mathrm{CD} 309^{+}$, cells $\times 10^{-1} / \mu \mathrm{L}$ & $2.96(\mathrm{IQR}=2.25-4.21)$ & $2.96(\mathrm{IQR}=2.30-4.24)$ & $2.95(\mathrm{IQR}=2.22-4.28)$ & 0.80 \\
\hline $\mathrm{CD}_{14} \mathrm{CCD}^{2} 09^{+} \mathrm{Tie}^{2+} \times 10^{-4}, \%$ & $5.50(\mathrm{IQR}=3.05-8.15)$ & $5.53(\mathrm{IQR}=3.20-8.10)$ & $5.48(\mathrm{IQR}=3.00-8.20)$ & 0.64 \\
\hline $\begin{array}{l}\text { CD14 }{ }^{+} \text {CD309 }{ }^{+} \mathrm{Tie}^{2+}, \\
\text { cells } \times 10^{-1} / \mu \mathrm{L}\end{array}$ & $0.270(\mathrm{IQR}=0.241-0.411)$ & $0.265(\mathrm{IQR}=0.243-0.410)$ & $0.272(\mathrm{IQR}=0.240-0.418)$ & 0.71 \\
\hline
\end{tabular}

Note: The values correspond to medians and a interquartile range (IQR) of (25-75)\%. Statistical comparisons are made using Mann-Whitney test with significance levels of 0.05 and 0.01 (for 2-tailed).

tor blocker valsartan. It should be noted that the chronic blockade of the renin-angiotensin system had a positive impact on increase of circulating EPC subpopulation with the phenotypes of CD14+CD309+ and $\mathrm{CD} 14^{+} \mathrm{CD} 309^{+} \mathrm{Tie}^{+}$, while the content of $\mathrm{CD}_{34}^{+}$of EPC did not change. We can assume that valsartan through the Akt-kinase me- chanism and expression of the transforming growth factor- $\beta$ can regulate differentiation and EPC mobbing [9, 23]. Indeed, in some earlier studies the association between the reduced EPCs pool and the Akt-kinase activity of the system was observed [22]. The antiproliferative effect of valsartan is implemented through suppression of the excessive activity of intracellular signaling systems HIF/ p-Akt/p-eNOS/MMP-9, which, in turn, may be associated with increased differentiation and the functional activity of ECPs. At the same time the implementation of the basic mechanisms for this effect is not fully understood. However, the given possibility of in-

Table 3

\section{Follow-up frequencies and absolute values of circulating mononuclear cells in treatment cohorts}

\begin{tabular}{|c|c|c|}
\hline Parameters & $\begin{array}{l}\text { Cohort with a low daily dose } \\
\text { of valsartan }(n=46)\end{array}$ & $\begin{array}{c}\text { Cohort with a high daily dose } \\
\text { of valsartan }(n=40)\end{array}$ \\
\hline $\mathrm{CD}^{2} 5^{+} \mathrm{CD} 34^{+}(\%)$ at baseline & $2.14(\mathrm{IQR}=1.79-2.50)$ & $2.23(\mathrm{IQR}=1.74-2.751)$ \\
\hline $\mathrm{CD}^{2} 5^{+} \mathrm{CD} 4^{+}(\%)$ follow-up & $2.12(\mathrm{IQR}=1.82-2.54)$ & $2.24(\mathrm{IQR}=1.80-2.93)$ \\
\hline $\mathrm{CD}^{2} 5^{+} \mathrm{CD} 34^{+}\left(\right.$cells $\left.\times 10^{3} / \mu \mathrm{L}\right)$ at baseline & $0.114(\mathrm{IQR}=0.095-0.120)$ & $0.113(\mathrm{IQR}=0.092-0.121)$ \\
\hline $\mathrm{CD}^{2} 5^{+} \mathrm{CD}_{34} 4^{+}$(cells $\left.\times 10^{3} / \mu \mathrm{L}\right)$ follow up & $0.118(\mathrm{IQR}=0.098-0.128)$ & $0.119(\mathrm{IQR}=0.103-0.132)$ \\
\hline $\mathrm{CD}^{2} 5^{-} \mathrm{CD} 4^{+} \times 10^{-4}(\%)$ at baseline & $1.07(\mathrm{IQR}=0.99-1.35)$ & $1.10(\mathrm{IQR}=0.99-1.365)$ \\
\hline CD45-CD34+ $\times 10^{-4}(\%)$ follow-up & $1.06(\mathrm{IQR}=0.97-1.36)$ & $1.11(\mathrm{IQR}=1.02-1.38)$ \\
\hline $\mathrm{CD}^{2} 5^{-} \mathrm{CD} 34^{+}\left(\right.$cells $\left.\times 10^{-1} / \mu \mathrm{L}\right)$ at baseline & $0.055(\mathrm{IQR}=0.052-0.067)$ & $0.058(\mathrm{IQR}=0.051-0.068)$ \\
\hline 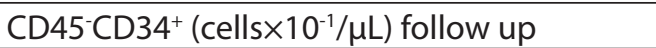 & $0.059(\mathrm{IQR}=0.055-0.066)$ & $0.061(\mathrm{IQR}=0.055-0.066)$ \\
\hline $\mathrm{CD}^{2} 4^{+} \mathrm{CD}_{309^{+} \times 10^{-4}(\%) \text { at baseline }}$ & $57.00(\mathrm{IQR}=41.50-76.90)$ & $58.10(\mathrm{IQR}=43.50-82.80)$ \\
\hline $\mathrm{CD}^{2} 4^{+} \mathrm{CD} 309^{+} \times 10^{-4}(\%)$ follow up & $73.00(\mathrm{IQR}=58.20-84.50)^{*}$ & $82.10(\mathrm{IQR}=65.10-99.30)^{*}$ \\
\hline $\mathrm{CD} 14^{+} \mathrm{CD} 309^{+}\left(\right.$cells $\left.\times 10^{-1} / \mu \mathrm{L}\right)$ at baseline & $2.96(\mathrm{IQR}=2.30-4.24)$ & $2.95(\mathrm{IQR}=2.22-4.28)$ \\
\hline $\mathrm{CD}^{2} 4^{+} \mathrm{CD} 309^{+}$(cells $\left.\times 10^{-1} / \mu \mathrm{L}\right)$ follow up & $4.92(\mathrm{IQR}=3.20-6.71)^{*}$ & $5.54(\mathrm{IQR}=4.22-6.78)^{*}$ \\
\hline $\mathrm{CD}^{2} 4^{+} \mathrm{CD} 39^{+} \mathrm{Tie}^{2+} \times 10^{-4}(\%)$ at baseline & $5.53(\mathrm{IQR}=3.20-8.10)$ & $5.48(\mathrm{IQR}=3.00-8.20)$ \\
\hline $\mathrm{CD}^{2} 4^{+} \mathrm{CD} 309^{+} \mathrm{Tie}^{2+} \times 10^{-4}$ (\%)follow up & $5.66(\mathrm{IQR}=3.35-8.80)$ & $7.08(\mathrm{IQR}=5.760-11.10)^{*}$ \\
\hline $\mathrm{CD}^{+} 4^{+} \mathrm{CD} 309^{+} \mathrm{Tie}^{2+}\left(\right.$ cells $\left.\times 10^{-1} / \mu \mathrm{L}\right)$ at baseline & $0.265(\mathrm{IQR}=0.243-0.410)$ & $0.272(\mathrm{IQR}=0.240-0.418)$ \\
\hline $\mathrm{CD}^{2} 4^{+} \mathrm{CD} 39^{+} \mathrm{Tie}^{2+}$ (cells $\left.\times 10^{-1} / \mu \mathrm{L}\right)$ follow up & $0.321(\mathrm{IQR}=0.265-0.476)$ & $0.412(\mathrm{IQR}=0.370-0.541)^{*}$ \\
\hline
\end{tabular}

Note: correspond to medians and a interquartile range (IQR) of (25-75) \%. Statistical comparisons are made for each cohort between the values at baseline and follow-up. ${ }^{*}$ - statistically significant changes $(P<0.05)$. 
creasing the level of potentially proangiogenic EPCs using valsartan, as well as its ability to provide a dose-dependent effect on circulating levels of the latter may have a serious clinical significance. Probably, it is necessary to conduct a new research in this direction aiming at detailing the nature of the relationship between the use of valsartan and the functional activity of EPCs, as well as the ability of the drug to improve clinical outcomes in a population of patients with heart failure and type 2 diabetes mellitus.

CONCLUSIONS

1. In the cohort of patients with heart failure and type 2 diabetes melitus valsartan has no signifi- cant influence on the content of endothelial progenitor cells with $\mathrm{CD} 5^{+} \mathrm{CD} 34^{+}$and $\mathrm{CD} 45^{-} \mathrm{CD} 34^{+}$phenotypes.

2. Valsartan has the dose-dependent ability to increase the circulating levels of potential proangiogenic endothelial progenitor cells with the phenotypes of $\mathrm{CD}_{14}{ }^{+} \mathrm{CD} 309^{+}$and $\mathrm{CD} 14^{+} \mathrm{CD} 309^{+} \mathrm{Tie}^{+}$.

\section{REFERENCES}

1. Березин А., Кремзер А. // Серце та судини. - 2013. - №44 (4). - С. 37-46.

2. Agatston A., Janowitz W., Hildner F. et al. // J. Am. Coll. Cardiol. - 1994. - Vol. 15. - P. 827-832.

3. Agatston A., Janowitz W. // Circulation. - 1994. - Vol. 89. - P. 1908-1909.

4. Bakogiannis C., Tousoulis D., Androulakis E. et al.//Curr. Med. Chem. - 2012. - Vol. 19 (16). - P. 2597-2604.

5. Bellows C., Zhang Y., Simmons P. et al. // Obesity. - 2011. - Vol. 19 (8). - P. 1722-1726.

6. Bluemke D., Achenbach S., Budoff M. et al. // Circulation. - 2008. - Vol. 118. - P. 586-606.

7. Budoff M., Achenbach S., Blumenthal R. et al. // Circulation. - 2006. - Vol. 114. - P. 1761-1791.

8. Chen J., Zhang F., Tao Q. et al. // Clin. Sci. (Lond). - 2004. - Vol. 107. - P. 273-280.

9. Clarkin C.E., King A.J., Dhadda P. et al. // Stem Cells. - 2012. - Dec. 19; doi:10.1002/stem.1305.[Epub ahead of print]

10. Executive summary: Standards of medical care in diabetes - 2013 // Diabetes Care. - 2013. - Vol. 36. P. S4-10.

11. Friedewald W., Levy R., Fredrickson D. // Clin Chem. - 1972. - Vol. 18 (6). - P. 499-502.

12. Hill J., Zalos G., Halcox J. et al. // N. Engl. J. Med. - 2003. - Vol. 348. - P. 593-600.

13. Krankel N., Adams V., Linke A. et al. // Arterioscler. Thromb. Vasc. Biol. - 2005. - Vol. 25. - P. 698-703.

14. Levey A., Stevens L., Schmid C. et al. // Ann. Intern. Med. - 2009. - Vol. 150. - P. 604-612.

15. Liew A., Barry F., O’Brien T. // Bioessays. - 2006. - Vol. 28. - P. 261-270.

16. Ling L., Shen Y., Wang K. et al. // PLoS One. - 2012. - Vol. 7 (11). - P. 50739.

17. Loomans C., de Koning E., Staal F. et al.// Diabetes. - 2004. - Vol. 3. - P. 195-199.

18. Mikirova N., Casciari J., Hunninghake R., Beezley M. // Int. J. Med. Sci. - 2011. - Vol. 8 (6). - P. 445-452.

19. Morishita T., Uzui H., Nakano A. et al. // J. Atheroscler. Thromb. - 2012. - Vol. 19 (2). - P. 149-158.

20. Schiller N., Shah P., Crawford M. et al. // J. Am. Soc. Echocardiogr. - 1989. - Vol. 2. - P. 358-367.

21. Tung J., Parks D., Moore W. et al. // Clin. Immunol. - 2004. - Vol. 110. - P. 277-283.

22. Werner N., Kosiol S., Schiegl T. et al. // N. Engl. J. Med. - 2005. - Vol. 353. - P. 999-1007.

23. Zhao C., Wang M., Siu C. et al. // Cardiovasc. Diabetol. - 2012. - Vol. 11 (1). - P. 147.

ВПЛИВ БЛОКАТОРА РЕЦЕПТОРІВ АНГІОТЕНЗИНУ ІІ ВАЛСАРТАНУ НА РІВЕНЬ ЦИРКУЛЮЮЧИХ ЕНДОТЕЛІАЛЬНИХ ПРОГЕНІТОРНИХ КЛІТИН У ПАЦІЄНТІВ 3 ХРОНІЧНОЮ СЕРЦЕВОЮ НЕДОСТАТНІСТЮ ІШЕМІЧНОГО ГЕНЕЗУ В ПОЄДНАННІ 3 ЦУКРОВИМ ДІАБЕТОМ 2 ТИПУ

о.о.кремзер

Запорізький державний медичний університет

Ключові слова: ішемічна хвороба серця; серцева недостатність; иукровий діабет 2 типу; циркулюючі ендотеліальні прогеніторні клітини; валсартан

Зниження циркулюючих ендотеліальних клітин-попередників (ЕКП) розглядається як прогностичний біомаркер серцево-судинних подій у пацієнтів з хронічною серцевою недостатністю і цукровим діабетом 2 типу (ЦД). Метою даного дослідження була оцінка ефекту блокатора рецепторів ангіотензину II валсартану щодо циркулюючого рівня ЕКП у хворих з хронічною серцевою недостатністю ішемічного генезу в поєднанні з иукровим діабетом 2 типу. Після підтвердження ІХС за допомогою мультиспіральної комп'ютерної томографії/ангіографії зонтрастним посиленням або рентгеноконтрастною коронарографією в дослідження було ретроспективно включено 126 пацієнтів з ХСН в поєднанні з ЦД 2 типу. Всі пацієнти були розподілені на дві когорти залежно від добової дози валсартану. Були використані низькі (80-160 мг на день) і високі (240-320 мг на день) дози валсартану, які були скореговані залежно від досягнення рівня АТ менше 140/80 мм рт. ст. Період спостереження складав 
52 тижні. Зміна загальної кількості CD34+ ЕКП у двох групах пацієнтів протягом періоду спостереження не носила статистично значимого характеру. Спостерігалося суттєве підвищення рівня циркулюючих $C D 14^{+} C D 309^{+}$ ЕКП до кінця 52 тижня терапії у двох групах хворих. Однак більш виражена динаміка відзначалася у пацієнтів, які отримували валсартан у високих добових дозах. Таким чином, вміст валсартану чинив виразний дозозалежний ефект щодо циркулюючого рівня проангіогенних ЕКП з фенотипами $C D 14^{+} C D 309^{+}$i CD14+CD309+Tie2+, mоді як пул CD34+ ЕКП не зазнавав істотних змін протягом всього періоду спостереження. Отже, блокатор рецепторів ангіотензину II валсартан чинить дозозалежний позитивний вплив на кількість циркулюючих ендотеліальних прогеніторних клітин кістковомозкового походження, фенотипованих як CD14+CD309+ $\mathrm{CD}^{+} 4^{+} \mathrm{CD} 309^{+} \mathrm{Tie2}^{+}$у хворих з ХСН ішемічного генезу в поєднанні з ЦД 2 типу.

\title{
ВЛИЯНИЕ БЛОКАТОРА РЕЦЕПТОРОВ АНГИОТЕНЗИНА ІІ ВАЛСАРТАНА НА УРОВЕНЬ ЦИРКУЛИРУЮЩИХ ЭНДОТЕЛИАЛЬНЫХ ПРОГЕНИТОРНЫХ КЛЕТОК У ПАЦИЕНТОВ С ХРОНИЧЕСКОЙ СЕРДЕЧНОЙ НЕДОСТАТОЧНОСТЬЮ ИШЕМИЧЕСКОГО ГЕНЕЗА В СОЧЕТАНИИ С САХАРНЫМ ДИАБЕТОМ 2 ТИПА
}

\section{А.А.Кремзер}

\section{Запорожский государственный медицинский университет}

Ключевые слова: ишемическая болезнь сердца; сердечная недостаточность; сахарный диабет 2 типа; циркулирующие эндотелиальные прогениторные клетки; валсартан

\begin{abstract}
Снижение циркулирующих эндотелиальных клеток-предшественников (ЭКП) рассматривается в качестве прогностического биомаркера сердечно-сосудистых исходов у пациентов с хронической сердечной недостаточностью и сахарным диабетом 2 типа. Целью данного исследования была оценка эффекта блокатора рецепторов ангиотензина II валсартана в отношении циркулирующего уровня ЭКП у больных с хронической сердечной недостаточностью ишемического генеза в сочетании с сахарным диабетом 2 типа. После подтверждения ИБС с помощью мультиспиральной компьютерной томографии/ангиографии с контрастным усилением или рентгеноконтрастной коронарографией в исследование было ретроспективно включено в 126 пациентов с ХСН в сочетании с сахарным диабетом 2 типа. Все пациенты были распределены на две когорты в зависимости от суточной дозы валсартана. Были использованы низкие (80-160 мг в день) и высокие (240-320 мг в день) дозы валсартана, скорректированные в зависимости от достижения уровня АД менее 140/80 мм рт. Период наблюдения составил 52 недели. Изменение общего количества CD34+ ЭКП в двух группах пациентов на протяжении периода наблюдения не носила статистически значимого характера. Имело место существенное повышение

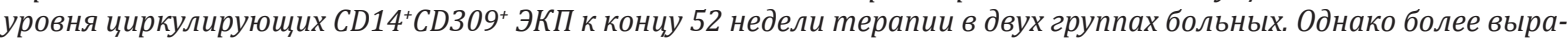
женная динамика отмечалась у пациентов, получающих валсартан в высоких суточных дозах. Таким образом, валсартан оказывал отчётливый дозозависимый эффект в отношении циркулирующего уровня проангиоген-

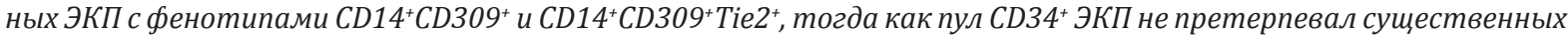
изменений на протяжении всего периода наблюдения. Таким образом, блокатор рещепторов ангиотензина II валсартан оказывает дозозависимое позитивное влияние на количество циркулирующих эндотелиальных прогениторных клеток костномозгового происхождения, фенотипированных как CD14+CD309+ u CD14 $^{+} \mathrm{CD} 309^{+} \mathrm{Tie2}^{+}$ у больных с ХСН ишемического генеза в сочетании с СД 2 типа.
\end{abstract}

Address for correspondence:

Received in 01.03.2014

26, Mayakovsky av., Zaporizhzhia, 69035, Ukraine.

Tel. (67) 618-03-02. E-mail: kremzer@gmail.com.

Zaporizhzhia State Medical University 